\title{
The Effect of CSR Attributes on CSR Authenticity: Focusing on Mediating Effects of Digital Transformation
}

\author{
Huifang Liu and Jin-Sup Jung *
}

Citation: Liu, H.; Jung, J.-S. The Effect of CSR Attributes on CSR Authenticity: Focusing on Mediating Effects of Digital Transformation. Sustainability 2021, 13, 7206. https:// doi.org/10.3390/su13137206

Academic Editors: Byung Il Park,

Andrea Pérez and Simon

Shufeng Xiao

Received: 22 May 2021

Accepted: 18 June 2021

Published: 28 June 2021

Publisher's Note: MDPI stays neutral with regard to jurisdictional claims in published maps and institutional affiliations.

Copyright: (c) 2021 by the authors. Licensee MDPI, Basel, Switzerland. This article is an open access article distributed under the terms and conditions of the Creative Commons Attribution (CC BY) license (https:/ / creativecommons.org/licenses/by/ $4.0 /)$.

\author{
Department of International Business, Chungbuk National University, Cheongju 28644, Korea; \\ lhf0202@cbnu.ac.kr \\ * Correspondence: jsjung@cbnu.ac.kr
}

\begin{abstract}
What corporate social responsibility (CSR) attributes determine the CSR authenticity of a company? In the face of the Fourth Industrial Revolution, what direction should the CSR strategy pursue? In the electronics industries in Korea and China, are there any differences in CSR attributes? In this study, we start with some of these basic questions. Considering the promotional and actual costs incurred from CSR activities, CSR strategy are not an issue that can be easily determined from the corporate perspective. However, now it is essential for companies to carry out CSR and sustainable development goals (SDGs) activities, and businesses cannot overlook social issues either. Companies cannot pursue only growth through corporate interests without social value. In this study, we derive three attributes of CSR fit, CSR sustainability, and CSR impact to verify the authenticity of CSR activities. Moreover, we demonstrated the impact of these three attributes on CSR authenticity for the electronics industries in Korea and China. As a result of empirical testing, most of three attributes above mentioned (i.e., CSR fit, CSR sustainability, and CSR impact) produce meaningful results for CSR authenticity. However, CSR sustainability was rejected for the Korea sample, and CSR fit was rejected for the Chinese sample, showing some differences between the two countries. Meanwhile, the digital transformation of the Fourth Industrial Revolution had strong partial mediating effects between CSR attributes and CSR authenticity. This means that digital transformation can be an important pathway to achieve CSR authenticity and suggests that important mediating effects can eventually lead to a firm's competitiveness.
\end{abstract}

Keywords: Fourth Industrial Revolution; CSR authenticity; digital transformation; mediating effect; China; Korea

\section{Introduction}

The Fourth Industrial Revolution (FIR) and COVID-19 pandemic are accelerating the creation of new business environments. In addition, in this new era, stakeholders demand greater amounts of corporate social responsibility (CSR) activities than in the past [1,2]. In addition, the FIR and COVID-19 pandemic are expected to bring about greater social change in the near future. Due to these reasons, most companies now feel the need to actively participate in social responsibility activities, recognizing them as an essential component of management activities. In particular, there is increased interest in effective CSR strategies that can draw consumers' interest and participation in management strategies and marketing [3-5].

Corporate CSR activities have played a pivotal role in positively changing consumer perceptions in the face of corporate crises and have evolved into an important element of corporate competitiveness [6-8]. As such, consumer awareness of CSR activities and CSR participation continue to increase, while some studies show that consumer assessment of corporate CSR activities is not positive. Moreover, CSR is often recognized as a short-term marketing activity to enhance the company's image, and skepticism exists about whether CSR truly contributes to society. In other words, if we believe that an entity is engaged in CSR activities for short-term profit, we are skeptical of the entity's CSR activities and, as a 
result, we have a negative assessment of CSR activities [9]. Therefore, in order to study the effectiveness of CSR activities, factor such as the sustainability of CSR need to be addressed, which is an issue of whether CSR activities are performed consistently [10].

One of the major research topics in CSR-related research is the "fit" that shows similarities between CSR activities and the company's core products and services [11]. This "fit" is one of the key factors in determining the effectiveness of CSR activities, with many studies focusing on related issues [12,13]. The literature has identified important factors of CSR authenticity (CA). Moreover, CA has proven to have a positive impact on consumers' overall perception of CSR activities [14].

"CSR fit" (CF) is the extent to which an entity's stakeholders recognize the relationship between the company and its CSR activities. On the other hand, "CA" indicates that an entity performs CSR activities for the benefit of the society. CA refers to consumers' actual trust in CSR behavior [15] and is an important factor in influencing the evaluation of CSR activities [14,16]. Especially, the attributes of CSR activities were divided into economic, legal, ethical, and discretionary responsibilities based on the study of Carroll (1979) [17]. This study selected and analyzed attributes of CSR activities that included CF, CSR sustainability (CS), and CSR impact (CI). Therefore, in this study, we define the attributes of enterprise activities as CSR characteristics that emerge when an enterprise performs CSR activities. For example, typical characteristics of CSR activities are that they consistently perform social responsibilities, have a great effect on social problem solving, or that they match with the corporate image.

In the digital age, CSR and digital transformation (DT) are becoming critical factors of a company's competitiveness [18]. Especially, DT is the most important element of the FIR, changing the way business is performed [19]. The FIR is affecting the overall industrial structure by reducing transaction costs due to the digital economy and meeting customized consumption trends [20]. Because the way business is conducted is affected by environmental, social, and economic trends, DT affects the sustainability of business models [21]. Naturally, it also plays an important role not only in the company's business model but also in the company's performance of social responsibility. For example, in some companies, the big data analysis of existing patents on social problems that are closely related to people's lives can diagnose problems and derive technical solutions.

Therefore, this study aims to achieve the following. First, this study explores the attributes of CSR activities based on the relevant existing research, which was divided into three main categories: CF, CS, and CI. We also examine the impact of these attributes on the authenticity of CSR. Second, we consider the "mediating effect of DT" between these attributes and CA. It is believed that this research model will not only provide important insights for future CSR strategies but also contribute to the theoretical foundation of CSR activities in response to the FIR.

Subsequently, this study was conducted as follows. In the following section, we discuss the theory of the major variables associated with this research model, including the attributes of CSR, the authenticity of CSR, and DT. The next section presents our research model by establishing our hypotheses. In Section 4, we carry out the empirical analysis. Finally, in Sections 5 and 6, we summarize our findings and suggest valuable implications.

\section{Literature Review}

CSR activities not only involve corporate social contributions but are also considered strategic elements of a company's sustainable growth and are recognized as essential for corporate management activities [1]. The most commonly used definition of organizing and explaining the concept of CSR is the definition of Carroll (1979) [17]. He divided attributes of the overall CSR activities into more detailed economic, legal, ethical, and discretionary responsibilities. He also argued that these four attributes of CSR activities form a hierarchical pyramid from lower-level economic responsibility to higher-level discretionary responsibility. In general, strategic CSR activities that efficiently use limited resources to establish a virtuous cycle between economic performance and social contributions are 
insufficient. Consequently, reflecting this reality, one of the important areas of CSR research is exploring the attributes of CSR activities that determine performance [22]. Therefore, we also want to focus on the main attributes of CSR activities and performance.

\subsection{Attributes of CSR}

Attributes of CSR are the factors associated with the attributes of CSR activities themselves. Existing studies involving antecedent variables of CSR authenticity show that the attributes of CSR activities will have a positive impact on CA [23]. Existing studies related to CA show that the attributes of CSR activities will have a positive effect on CA [1,24]. In a study by An, Seo, and Lee [25], three attributes of CF, CSR consistency, and CI, were selected as components of $\mathrm{CA}$. Their research target was a franchise company and considered the impact of CSR activities at franchise headquarters on franchisees' perceptions. Beckman and Colwell [14] have derived seven variables that affect CA, including relevance, transparency, impact, and consistency. In our study, we define attributes of corporate activities as CSR features that appear when companies perform CSR activities, and we hope to use these CSR features when verifying the effectiveness of CSR activities. Based on these prior studies, this study aims to distinguish attributes of CSR activities into three main categories of CF, CS, and CI. We will now discuss these categories in greater detail.

\subsubsection{CSR Sustainability (CS)}

CS is the possibility that CSR activities can be maintained continuously through "persistence" and "consistency". In this regard, "consistency" is one of the main variables in determining motives and whether a particular behavior or attitude of the target is maintained from beginning to end. This attribute is a concept that many CSR studies have also noted [22,26-28]. While consistent information usually leads to a positive response by reducing consumers' efforts to refine and explore information, inconsistent information leads to confusion and antagonizes existing information, resulting in a negative response.

Sustainability presented in this study relates to "keeping CSR activities consistent" (systematically aligned with the overall firm's strategy) with an entity's resource commitment, objectives, and performance tactics from start to finish "continuously". In other words, for CS activities, "continuously" includes the cost, resources, and time invested by an entity are consistent and consistently in accordance with the corporate strategy $[25,29,30]$. Ellen, Webb, and Mohr [31] argued that experimental research has a positive impact only if consumers recognize persistence in the CSR activities of a target entity.

\subsubsection{CSR Fit (CF)}

In order to carry out CSR more strategically, it is necessary to examine the fit of social contribution activities [1,9]. The fit of CSR activities is valued when consumers recognize the comprehensive activities of an enterprise (e.g., business or product line, corporate image, market positioning, target market, corporate mission). CF is the perceived conformity between the attributes of the enterprise and CSR activities [32]. Ellen, Webb, and Mohr [31] defined "fit" in cause marketing as "a recognized link among the company's product line, brand image, brand positioning, or target market". They demonstrated that fit between businesses and CSR activities is a key factor in successful CSR and showed that a higher CF makes consumer evaluations more positive. Pracejus and Olsen [33] suggested that the public appreciates the value of a company's contribution if the company's contribution activities are more consistent with its nature. This is because the more social contribution activities of companies align with corporate characteristics, the more favorable they are to consumers. Therefore, in the CSR literature, $\mathrm{CF}$ is a relational relationship between the attributes of the enterprise and the CSR activities it implements [34].

\subsubsection{CSR Impact (CI)}

"CI" refers to the extent to which CSR activities have substantially resulted in the resolution of social problems [35]. In other words, CI refers to the importance of the social 
problem that the company intends to support and the recognition of the degree to which the CSR activity contributes substantially to the resolution of the social problems [36]. Bae [37] defined CI as "a way to express how positive social contribution activities in question bring positive benefits to society or beneficiaries". In addition, emphasizing the social impact of an enterprise's CSR commitment or CSR efforts is an effective communication strategy because CSR communication should be realistic and avoid the impression of "bragging" [38].

Positive effects of CSR activities include improved image and attitude toward companies that perform CSR, improved stakeholder satisfaction, enhanced buffer against corporate crises, increased future acquisition of potential customers or employees, increased likelihood of companies and products, and increased purchase intentions [39-41]. According to Alhouti et al. [36], CI has a positive effect on CA. Holbrook [42] shows that the greater the $\mathrm{CI}$, the more likely it is to interpret $\mathrm{CA}$ as altruistically motivated activities.

\subsection{Authenticity of CSR (CA)}

Most studies on CA have shown that the evaluation of CSR activities has been treated as important variables, especially with regard to negative perceptions such as commercial intentions [12,43].

Price, Arnould, and Tierney [44] found that authenticity is not done because of social obligations or responsibilities but with genuine consideration for others. Many studies of authenticity have also been conducted in the CSR research, which state that authenticity is present when the internal motivation for CSR activities matches external behaviors [45].

The authenticity of CSR activities is related to whether a company acts honestly by showing its sincerity to consumers throughout the entire process of CSR marketing activities, explaining whether a company's social contribution activities are genuine activities to solve social and environmental problems [12,43]. CA is the subjective and overall assessment of how truthful a company is and is seen as the basis for determining how sincere and responsible CSR activities are perceived by consumers [46].

If CSR activities are perceived as being purely motivated for social contribution, they are judged to be genuine acts, resulting in favorable responses toward the company as well as the act itself [31,38]. On the other hand, activities derived from the purpose of seeking profit may be assessed as lacking sincerity, resulting in a negative response.

\subsection{Digital Transformation (DT) in the Era of the Fourth Industrial Revolution}

The FIR has brought about massive changes in industry as well as society with the advent of new business models and the destruction of existing systems, production and consumption patterns, and transportation and delivery systems [47]. Companies are innovating existing services by combining their products with various information and communication technologies (ICTs), such as the internet of things (IoT), artificial intelligence (AI), and big data. All of these actions are called "digital transformation".

DT is a strategy for companies to integrate digital and physical components to change business models and establish new directions in their industry [48]. DT typically refers to the process of creating new value and building appropriate business models by using digital technology to dismantle and reorganize existing value chains [49]. Moreover, companies can promote their economic interests while also creating social value [6,7]. So, can not DT of enterprises enhance the authenticity of CSR activities? This study focuses on this question.

At the core of the FIR is the DT in all areas of individuals and companies, especially from a corporate perspective, which means innovation in corporate operations through digitalization [50]. In 2004, Professor Erik Stolterman of Sweden first referred to "DT" as "a phenomenon in which human life improves in a better way by utilizing IT technology". At the firm level, many businesses apply digital technology to improve business models.

DT is important for companies through the connection of things to things, real-time accumulation and analysis of information, product serviceization, and service produc- 
tion [51]. In particular, this DT is critical for the "flexibility" it provides. In terms of business, DT is not just about achieving business performance through the application of digital technology but rather about creating new added value, new business models, and changes in the enterprise [52].

In January 2016, the WEF (World Economic Forum) published a white paper titled "Digital Enterprise" in collaboration with Accenture, a consulting firm, under the theme "DT of Industries". This paper states that more fundamental changes are required for analog companies to change into digital companies. Four key factors were identified that included exploring new business models, reexamining underlying digital operational models, strengthening digital capabilities using talent and skills, and expanding new digital traction metrics (Table 1).

Table 1. Four key factors and detailed description of each factor by WEF.

\begin{tabular}{ccc}
\hline & Core Requirements & Specifications of Each Core Requirement \\
\hline 1 & Digital business models & $\begin{array}{c}\text { Identify, develop and launch new, digital business models } \\
\text { Set up a successful corporate venturing business }\end{array}$ \\
\hline 2 & Digital operating models & $\begin{array}{c}\text { Re-examine every aspect of operations } \\
\text { Understand and leverage data }\end{array}$ \\
\hline 3 & Digital talent and skills & $\begin{array}{c}\text { Consider increasing your investments in security } \\
\text { Build a high-quotient digital workforce }\end{array}$ \\
\hline 4 & Digital traction metrics & Convince your investors about your digital transformation journey
\end{tabular}

Source: WEF (2017) “World Economic Forum White Paper (2016)".

According to Orbik and Zozulakova [18], CSR and DT are important factors in upgrading global competitiveness in the modern society. DT reduces the impact on the envi-ronment and expands talent diversity, enabling companies to comply with their social responsibilities [53]. Furthermore, higher digital maturity, better governance structure, and more comprehensive ethics regulations reflect the response to social responsibilities re-quired by the enterprise [54].

Among the major fields of the FIR, mobile and online payment, sharing economy, ar-tificial intelligence, electric vehicles, autonomous vehicles, robots, and IoT are related to DT. Although these fields exhibit different characteristics, they have common characteristics in terms of changing existing business models and strengthening competitiveness. Therefore, governments and companies need to identify DT policy trends, industry trends, business models, and strategies of major companies and industries. They should also seek ways to strengthen national and corporate competitiveness and new ways to cooperate each other with DT. Of course, if these changes are combined with Sustainable Development Goals (SDGs), which seek joint social and human prosperity beyond companies' economic value, they will have more positive effects.

\section{Research Methodology}

\subsection{Attributes and Authenticity of CSR}

Alhouti, Johnson, and Holloway [36] stated that consumers develop measures for attributes of perceived CSR and that CF, CI, and CSR compensation affect their CA. Furthermore, according to L'Etang [30], the persistence of CSR serves as a basis for determining whether an enterprise is conducting valuable CSR activities. The sustainability of CSR activities can have a positive impact on variables such as authenticity as well as overall evaluation. If this is incorporated into the CSR strategy, "the degree of continuous CSR activity of the company" can also be evaluated [26]. According to Ku and Shim [55], who verified the relationship between persistence and authenticity of CSR activities found that subjects also appreciate their authenticity if the persistence of CSR activities is high. A study by Park and Hwang [46] showed that CSR activities are perceived as authentic if they are consistently and continuously performed. Choi, Hwang, and An [56] found that consumers' perceptions of the four attributes of CSR: persistence, fit, impact, and differentiation, directly affect CA. A study by Kim and Lee [1] found that CF has a positive effect 
on both CA and brand attitude. Holbrook [42] found that greater CI results in a greater likelihood of interpreting CA as altruistically-motivated. Furthermore, research by An, Wang, and Jeon [57] showed that the evaluation of CA is positive if an entity performs CSR activities on a scale that can contribute to solving social problems of high social interest. Hence, we propose the following hypotheses.

Hypothesis 1 (H1). CSR attributes will have a positive effect on the authenticity of CSR (or CSR authenticity).

Hypothesis 1-1 (H1-1). The sustainability of CSR initiatives will have a positive effect on the authenticity of CSR.

Hypothesis 1-2 (H1-2). The fit of CSR initiatives will have a positive effect on the authenticity of CSR.

Hypothesis 1-3 (H1-3). The impact of CSR initiatives will have a positive effect on the authenticity of CSR.

\subsection{Mediating Effect of Digital Transformation}

Today's relationship between business (or economic value) and moral (or social value) takes on CSR principles-based corporate activity forms, and the Internet and mobile devices have become efficient CSR communication and upgrading tools for enterprise organizations in the digital age. For example, DT has already greatly contributed to reducing pollutant emissions and increasing environmental protection, allowing people to solve existing problems in a more environmentally friendly way $[18,58]$. In addition, there seems to be little disagreement that digital transformation such as big data, the IoT, artificial intelligence, $\mathrm{AR} / \mathrm{VR}$, and robots will profoundly impact the labor sector. Summing up, CSR and DT are two of the most important factors of global competitiveness in the modern world [18].

Recently, global companies have strengthened their CSR activities by establishing an emergency management system to cope with the COVID-19 pandemic and actively participating in national emergency relief. In addition, governments are accelerating their push to reorganize the GVC and DT across all sectors to respond to the post-COVID era. Companies such as Sony (Japan), Seimens (Germany), Bing Group \& Vietel (Vietnam), and Strata (the United Arab Emirates) used their production facilities to produce Covid-19 quarantine products or provide quarantine services. In addition, businesses are further strengthening their market dominance of online platforms using DT, as people who want to be safe from the Covid-19 outbreak are reluctant to make face-to-face contact. These new digital technologies are likely to structurally change consumer behavior and recognition [59]. Further, DT alleviates the information asymmetry between companies and stakeholders (including consumers) by broadening information channels, thus strengthening the authenticity of CSR activities.

DT has already significantly contributed to the reduction of pollutant emissions and increased environmental protection [18]. There are several cases of pursuing environmental sustainability through DT. Tesco is leveraging AI analytics to measure the environmental impact of sales activities and achieve carbon reduction targets [60]. The U.S. construction industry is reducing construction waste, which accounts for 25 to 40 percent of solid waste, by using drones [61]. In the agricultural sector, 'robotization of herbicide work' has reduced farmhouse herbicide usage by 20 times compared to conventional methods [62].

Using digital technology to reduce the environmental impacts and the diversity of talent leads to improved financial performance. This is because reducing carbon emissions or resource consumption can result in cost savings. For example, Maersk, a global carrier, has reduced fuel costs by $13 \%$ over the past two years by optimizing speed and routes through data analysis of sensors installed on ships [63].

Consequently, DT can also play an intermediary role in strengthening the authenticity of CSR, given the number of successful cases in which the purpose of CSR and its 
core competency (or competitiveness) can be achieved simultaneously through digital transformation. Hence, we propose the following hypotheses.

Hypothesis 2 (H2). Digital transformation will have a positive mediating effect between the attributes of CSR and CSR authenticity.

Hypothesis 2-1 (H2-1). Digital transformation will have a positive mediating effect between CSR Sustainability and CSR authenticity.

Hypothesis 2-2 (H2-2). Digital transformation will have a positive mediating effect between CSR fit and CSR authenticity.

Hypothesis 2-3 (H2-3). Digital transformation will have a positive mediating effect between CSR impact and CSR authenticity.

The research model of this study, which combines the above hypotheses, is shown in Figure 1.

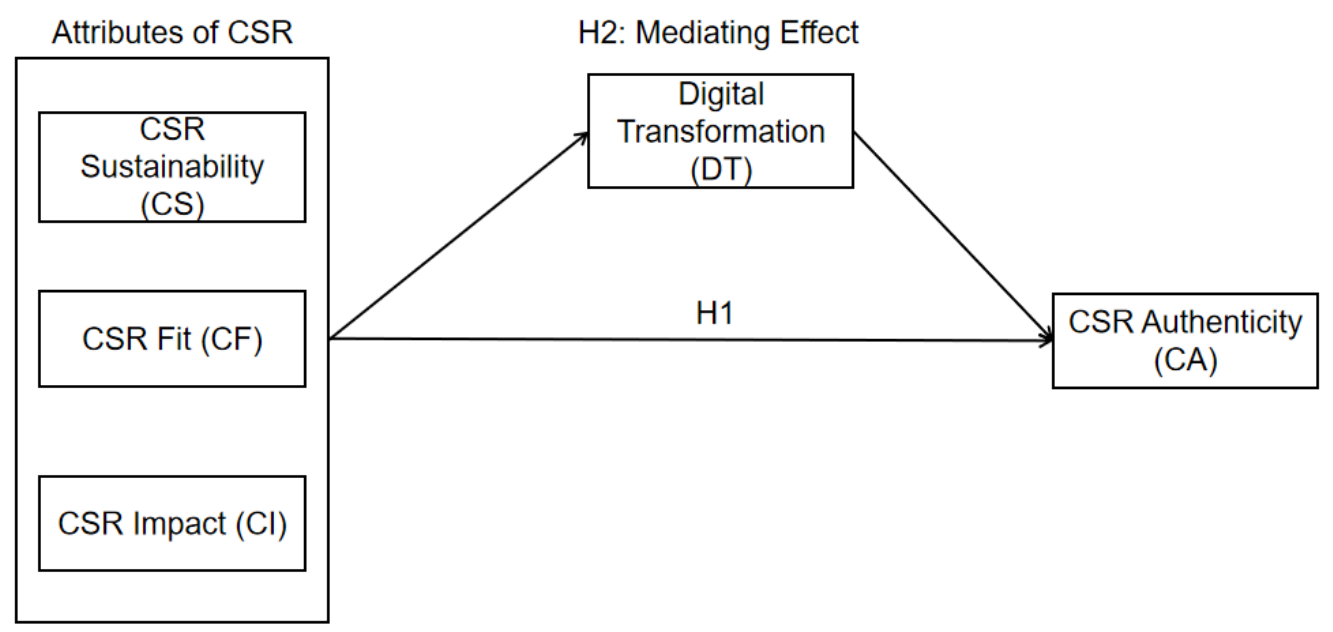

Figure 1. Conceptual model.

\section{Empirical Analysis}

In this study, data was collected through the use of questionnaires that used a fivepoint scale administered to general consumers who use electronic products in Korea and China. In the case of Korea, national leading electronics companies such as LG and Samsung were more specific target companies for CSR activities, while China were Xiaomi and Huawei. The survey period was from 20 January 2021, to 13 February 2021. In Korea, 200 questionnaires were collected mainly in Chungcheong Province, and 172 questionnaires were used in the final analysis, excluding 28 poor responses. In China, 200 questionnaires were collected mainly in Shandong and Hebei provinces, and 185 questionnaires were used for analysis, after excluding 15 inadequate responses. The sample characteristics of respondents are shown in Table 2.

\subsection{Reliability and Validity Analysis}

To assess the measurement qualities and discriminant validity of the model variables, a confirmatory factor analysis was conducted. The model includes items for CS, CF, CI, CA, and DT. The factor loadings of each item were higher than 0.5 , demonstrating convergent validity (see Table 3).

Reliability analysis was performed for reliability testing of measurement items. Cronbach's $\alpha$ was used for internal consistency testing. Results found that the reliability of items is valid since all measures exceeded 0.6. Results are shown in Table 4. 
Table 2. Characteristics of sample.

\begin{tabular}{cccccc}
\hline & Characteristics & No. (Korea) & \% (Korea) & No. (China) & \% (China) \\
\hline \multirow{3}{*}{ Gender } & Male & 99 & 57.6 & 83 & 44.9 \\
& Female & 73 & 42.4 & 102 & 55.1 \\
& $10-19$ & 10 & 5.8 & 5 & 2.7 \\
\multirow{4}{*}{ Age } & $20-29$ & 85 & 49.4 & 94 & 50.8 \\
& $30-39$ & 36 & 20.9 & 50 & 27.0 \\
& $40-49$ & 25 & 14.5 & 21 & 11.4 \\
& $\geq 50$ & 16 & 9.3 & 15 & 8.1 \\
\hline
\end{tabular}

Table 3. Variables and item description.

\begin{tabular}{|c|c|c|c|c|c|}
\hline \multirow{2}{*}{ Variables } & \multirow{2}{*}{ Items } & \multicolumn{2}{|c|}{ Korean } & \multicolumn{2}{|c|}{ China } \\
\hline & & Mean (SD) & Factor Loading & Mean (SD) & Factor Loading \\
\hline \multirow{4}{*}{ CS } & $\begin{array}{c}\text { The company has been conducting CSR activities for a } \\
\text { long time. }\end{array}$ & \multirow{4}{*}{$3.75(0.576)$} & 0.700 & \multirow{4}{*}{$4.01(0.600)$} & 0.809 \\
\hline & The company continues to carry out CSR activities. & & 0.778 & & 0.694 \\
\hline & $\begin{array}{l}\text { The entity is consistently performing CSR activities. } \\
\text { The company's CSR activities are systematic and are }\end{array}$ & & 0.795 & & 0.724 \\
\hline & $\begin{array}{c}\text { being carried out in accordance with the } \\
\text { company's goals. }\end{array}$ & & 0.698 & & 0.633 \\
\hline \multirow{4}{*}{$\mathrm{CF}$} & $\begin{array}{l}\text { The company's CSR activities are related to the } \\
\text { characteristics of the company. }\end{array}$ & \multirow{4}{*}{$3.77(0.610)$} & 0.799 & \multirow{4}{*}{$4.03(0.556)$} & 0.756 \\
\hline & $\begin{array}{l}\text { The company's CSR activities are highly similar to the } \\
\text { company's industry characteristics. }\end{array}$ & & 0.787 & & 0.648 \\
\hline & $\begin{array}{l}\text { The company's CSR activities are highly related to its } \\
\text { corporate image. }\end{array}$ & & 0.758 & & 0.705 \\
\hline & $\begin{array}{c}\text { The company's CSR activities are highly related to its } \\
\text { target customers. }\end{array}$ & & 0.712 & & / \\
\hline \multirow{5}{*}{$\mathrm{CI}$} & $\begin{array}{l}\text { The company's CSR activities are on a scale sufficient } \\
\text { to work. }\end{array}$ & \multirow{5}{*}{$3.76(0.634)$} & 0.658 & \multirow{5}{*}{$3.99(0.633)$} & / \\
\hline & $\begin{array}{l}\text { The company's CSR activities will help solve social } \\
\text { problems in the long term. }\end{array}$ & & 0.771 & & / \\
\hline & $\begin{array}{l}\text { The company's CSR activities are making a meaningful } \\
\text { contribution to solving social problems. }\end{array}$ & & 0.792 & & 0.645 \\
\hline & $\begin{array}{l}\text { The company's CSR activities help to recognize } \\
\text { social problems. }\end{array}$ & & 0.777 & & 0.778 \\
\hline & $\begin{array}{l}\text { The company's CSR activities make me willing } \\
\text { to participate. }\end{array}$ & & 0.609 & & 0.644 \\
\hline \multirow{4}{*}{ CA } & $\begin{array}{l}\text { I feel the belief that this company is working for the } \\
\text { public good. }\end{array}$ & \multirow{4}{*}{$3.59(0.671)$} & 0.598 & \multirow{4}{*}{$4.02(0.581)$} & 0.683 \\
\hline & I think the company's CSR activities are heartfelt. & & 0.769 & & 0.628 \\
\hline & $\begin{array}{l}\text { This company has consideration for members of } \\
\text { the society. }\end{array}$ & & 0.774 & & 0.702 \\
\hline & $\begin{array}{l}\text { I think this company's CSR activities are voluntary. } \\
\text { The company's CSR activities are sincere. }\end{array}$ & & $\begin{array}{l}0.766 \\
0.845\end{array}$ & & $\begin{array}{l}0.761 \\
0.749\end{array}$ \\
\hline \multirow{5}{*}{ DT } & $\begin{array}{c}\text { Companies can operate efficiently through digital } \\
\text { transformation. }\end{array}$ & \multirow{5}{*}{$4.02(0.629)$} & 0.804 & \multirow{5}{*}{$4.16(0.521)$} & 0.754 \\
\hline & $\begin{array}{l}\text { Business turnaround time is reduced through } \\
\text { digital transformation. }\end{array}$ & & 0.811 & & 0.723 \\
\hline & $\begin{array}{l}\text { Companies will reduce work costs through } \\
\text { digital transformation. }\end{array}$ & & 0.748 & & 0.521 \\
\hline & $\begin{array}{l}\text { Companies are more productive through } \\
\text { digital transformation. }\end{array}$ & & 0.816 & & 0.716 \\
\hline & $\begin{array}{l}\text { Business performance improves through } \\
\text { digital transformation. }\end{array}$ & & 0.655 & & 0.576 \\
\hline
\end{tabular}

Table 4. Correlation and reliability analysis (Korea).

\begin{tabular}{ccccccc}
\hline & CS & CF & CI & CA & DT & Cronbach's $\alpha$ \\
\hline CS & 1 & & & & & 0.706 \\
CF & $0.325^{* *}$ & 1 & & & & 0.727 \\
CI & $0.412^{* *}$ & $0.354^{* *}$ & 1 & & & 0.676 \\
CA & $0.324^{* *}$ & $0.365^{* *}$ & $0.470^{* *}$ & 1 & & 0.700 \\
DT & $0.422^{* *}$ & $0.274^{* *}$ & $0.425^{* *}$ & $0.355^{* *}$ & 1 & 0.706 \\
\hline
\end{tabular}

Notes: $\mathrm{N}=172 ;{ }^{* *} p<0.01$ (two-tailed test). 
In China, reliability analysis was also performed for measurement items. For this analysis, it is assumed that there are no significant problems because values exceeded the 0.7 threshold (see Table 5).

Table 5. Correlation and reliability analysis (China).

\begin{tabular}{ccccccc}
\hline & CS & CF & CI & CA & DT & Cronbach's $\alpha$ \\
\hline CS & 1 & & & & 0.734 \\
CF & $0.388^{* *}$ & 1 & & & 0.743 \\
CI & $0.422^{* *}$ & $0.485^{* *}$ & 1 & & 0.723 \\
CA & $0.387^{* *}$ & $0.304^{* *}$ & $0.404^{* *}$ & 1 & 0.760 \\
DT & $0.489^{* *}$ & $0.435^{* *}$ & $0.452^{* *}$ & $0.383^{* *}$ & 1 & 0.726 \\
\hline Notes: $\mathrm{N}=185^{* *}$ * & & & & \\
\hline
\end{tabular}

\subsection{Hypothesis Testing of Korean Samples}

Looking at the regression results of the independent variables (attributes of CSR) and dependent variables $(C A)$, two variables of $C F(\beta=0.204, t=2.848)$ and $C I(\beta=0.352, t=4.723)$ have statistically significant positive effects on CA. On the other hand, $C S(\beta=0.112, t=1.523)$ was not significant. Therefore, hypotheses 2-2 and 2-3 are supported, while hypothesis 2-1 is rejected (see Table 6). However, the simple regression analysis of CS and CA showed to be significant $(\beta=0.325, \mathrm{t}=4.484)$. Therefore, it is difficult to judge whether there is a causal relationship between the two variables. In summary, the higher the fit of CSR activities and the impact of CSR activities, the greater the CA.

Table 6. Multiple regression analysis (Korea).

\begin{tabular}{cccccc}
\hline Dependent Var. & $\begin{array}{c}\text { Independent } \\
\text { Variables }\end{array}$ & $\mathbf{R}^{2}$ & Adjusted $\mathbf{R}^{2}$ & $\mathbf{F}$ & $\boldsymbol{\beta}(\boldsymbol{t}$-Value $)$ \\
\hline \multirow{2}{*}{ CA } & CS & & & & $0.112(1.523)$ \\
& CF & 0.276 & 0.264 & 21.398 & $0.204\left(2.848^{* *}\right)$ \\
CI & & & $0.352\left(4.723^{* * *}\right)$ \\
\hline
\end{tabular}

Notes: ${ }^{* *} p<0.01, * * * p<0.001$.

As such, the preceding independent variables have a positive effect on consumer perception of authenticity for CSR activities. Therefore, if an entity engages in CSR activities, it needs to develop and implement marketing strategies that can have a great impact on long-term and appropriate levels of relevance and social issues.

Results for the mediating effects of digital transformations between independent and dependent variables are shown in Table 7. Variables of CS $(\beta=0.266, t=3.429)$, CF $(\beta=0.276, t=3.865)$, and $C I(\beta=0.19$ and $t=2.579)$ simultaneously influenced the dependent and parameters (i.e., direct and indirect effects) in stage 3.

\subsection{Hypothesis Testing of Chinese Samples}

Looking at the regression results of the independent variables (or CSR attributes) and dependent variables (CA), two variables, $C S(\beta=0.245, t=3.305)$ and $C I(\beta=0.26 ; t=3.324)$, have statistically significant positive effects on CA. On the other hand, $C F(\beta=0.083$ and $t=1.086$ ) was not significant. Therefore, hypotheses $2-1$ and 2-3 are supported, but hypothesis 2-2 is rejected (see Table 8). However, the simple regression analysis of CF and CA found CF to be significant $(\beta=0.304, t=4.324)$. Therefore, it is difficult to determine that there is no complete causal relationship between the two variables.

Verification results for the mediating effects of digital transformations between independent and dependent variables are shown in Table 9. A partial mediating effect was found that affects all the dependent variables and parameters simultaneously, including CS $(\beta=0.254, \mathrm{t}=3.338), \mathrm{CF}(\beta=0.308, \mathrm{t}=4.112)$, and $\mathrm{CI}(\beta=0.251, \mathrm{t}=3.411)$. 
Table 7. Mediating the effect test of digital transformation (Korea).

\begin{tabular}{|c|c|c|c|c|c|c|c|}
\hline & Stage of Mediating Test & $\beta$ & $t$ & $p$ & $\mathbf{R}^{2}$ & Adjusted $\mathrm{R}^{2}$ & Result of Test \\
\hline \multirow{4}{*}{$\mathrm{CS} / \mathrm{DT} / \mathrm{CA}$} & Stage 1 & 0.422 & 6.064 & 0.000 & 0.178 & 0.173 & \multirow{4}{*}{ Partial mediation } \\
\hline & Stage 2 & 0.324 & 4.461 & 0.000 & 0.105 & 0.100 & \\
\hline & Stage 3 (Ind_Var) & 0.211 & 2.725 & 0.007 & & & \\
\hline & Stage 3 (Med_Var) & 0.266 & 3.429 & 0.001 & 0.163 & 0.153 & \\
\hline \multirow{4}{*}{$\mathrm{CF} / \mathrm{DT} / \mathrm{CA}$} & Stage 1 & 0.274 & 3.721 & 0.000 & 0.075 & 0.070 & \multirow{4}{*}{ Partial mediation } \\
\hline & Stage 2 & 0.365 & 5.116 & 0.000 & 0.133 & 0.128 & \\
\hline & Stage 3 (Ind_Var) & 0.29 & 4.057 & 0.000 & & & \\
\hline & Stage 3 (Med_Var) & 0.276 & 3.865 & 0.000 & 0.204 & 0.194 & \\
\hline \multirow{4}{*}{$\mathrm{CI} / \mathrm{DT} / \mathrm{CA}$} & Stage 1 & 0.425 & 6.121 & 0.000 & 0.181 & 0.176 & \multirow{4}{*}{ Partial mediation } \\
\hline & Stage 2 & 0.47 & 6.95 & 0.000 & 0.221 & 0.217 & \\
\hline & Stage 3 (Ind_Var) & 0.39 & 5.299 & 0.000 & & & \\
\hline & Stage 3 (Med_Var) & 0.19 & 2.579 & 0.011 & 0.251 & 0.242 & \\
\hline
\end{tabular}

Table 8. Multiple regression analysis (China).

\begin{tabular}{cccccc}
\hline Dependent Var. & $\begin{array}{c}\text { Independent } \\
\text { Variables }\end{array}$ & $\mathbf{R}^{2}$ & Adjusted $\mathbf{R}^{2}$ & $\mathbf{F}$ & $\boldsymbol{\beta}(\boldsymbol{t}$-Value $)$ \\
\hline & $\mathrm{CS}$ & & & & $0.245\left(3.305^{* * *}\right)$ \\
$\mathrm{CA}$ & $\mathrm{CF}$ & 0.225 & 0.212 & 17.531 & $0.083(1.086)$ \\
& $\mathrm{CI}$ & & & $0.26\left(3.324^{* * *}\right)$ \\
\hline Notes: ${ }^{* * *} p<0.001$.
\end{tabular}

Table 9. Mediating effect test of digital transformation (China).

\begin{tabular}{|c|c|c|c|c|c|c|c|}
\hline & Stage of Mediating Test & $\beta$ & $t$ & $p$ & $\mathbf{R}^{2}$ & Adjusted $\mathrm{R}^{2}$ & Result of Test \\
\hline \multirow{4}{*}{$\mathrm{CS} / \mathrm{DT} / \mathrm{CA}$} & Stage 1 & 0.489 & 7.590 & 0.000 & 0.239 & 0.235 & \multirow{4}{*}{ Partial mediation } \\
\hline & Stage 2 & 0.387 & 5.678 & 0.000 & 0.150 & 0.145 & \\
\hline & Stage 3 (Ind_Var) & 0.263 & 3.454 & 0.001 & & & \\
\hline & Stage 3 (Med_Var) & 0.254 & 3.338 & 0.001 & 0.199 & 0.190 & \\
\hline \multirow{4}{*}{$\mathrm{CF} / \mathrm{DT} / \mathrm{CA}$} & Stage 1 & 0.435 & 6.539 & 0.000 & 0.189 & 0.185 & \multirow{4}{*}{ Partial mediation } \\
\hline & Stage 2 & 0.304 & 4.324 & 0.000 & 0.093 & 0.088 & \\
\hline & Stage 3 (Ind_Var) & 0.170 & 2.270 & 0.024 & & & \\
\hline & Stage 3 (Med_Var) & 0.308 & 4.112 & 0.000 & 0.170 & 0.161 & \\
\hline \multirow{4}{*}{$\mathrm{CI} / \mathrm{DT} / \mathrm{CA}$} & Stage 1 & 0.452 & 6.858 & 0.000 & 0.204 & 0.200 & \multirow{4}{*}{ Partial mediation } \\
\hline & Stage 2 & 0.404 & 5.968 & 0.000 & 0.163 & 0.158 & \\
\hline & Stage 3 (Ind_Var) & 0.290 & 3.933 & 0.000 & & & \\
\hline & Stage 3 (Med_Var) & 0.251 & 3.411 & 0.001 & 0.213 & 0.205 & \\
\hline
\end{tabular}

\section{Discussion and Conclusions}

Society-wide awareness of CSR activities has gone beyond passive donations or simple support, introducing a view of creating shared values (CSV) through social problemsolving $[6,7]$. Although CSR activities are increasing, consumers today want genuine CSR activities rather than campaigns aimed solely at short-term corporate profits $[3,64,65]$.

This paper aims to enhance the understanding of the antecedent variables $(\mathrm{CS}, \mathrm{CF}, \mathrm{CI})$ and their effects on CA. Furthermore, we consider the mediating effects of DT between attributes of CSR activities and CA. We conducted empirical analyses to verify our research model. With the onset of the FIR, most of the industries are actively developing and transforming, but the electronics industry, in particular, has been more affected than other industries. Moreover, we think CSR activities differ based on the industry. Therefore, we chose the electronics industry for our research. Meanwhile, Korea and China also have different social systems based on capitalism and socialism, which can affect CSR activities differently. Therefore, the Korean and Chinese electronic industries were selected for our CSR study. The summary and analysis of our results are as follows. 
According to our Korean sample, CF and CI, which are attributes of CSR, had a positive effect on CA. On the other hand, CS did not show statistical significance when performing multiple regression analyses. However, it was statistically significant when simple regression was performed.

In analyzing multiple regression of the Korean sample, why was CS rejected? Usually, consumers not only have a positive attitude toward CSR activities but also appreciate the authenticity of CSR activities if CSR activities are judged to have been "continuously" executed [26]. Therefore, in the Korean sample, the rejection of CS in multiple regression should be more comprehensive and flexible, rather than interpreting that CS has no impact on the authenticity of CSR. In other words, although the impact of CS is smaller than the other two attributes (or CF, CI), it should be understood that $\mathrm{CS}$ also has a positive impact on CA since simple regression shows significant statistically. According to Kelly [28], consumers' contact with persistent or consistent stimuli causes "dispositional attribution (性向歸因)". In other words, in the case of the electronics industry in South Korea, it can be suggested that CSR activities should be continuously carried out regardless of the company's situation.

On the other hand, for the Chinese data, CS and CI, which are attributes of CSR activities, had a positive effect on CA. On the other hand, CF was not significant when performing multiple regression analyses. However, it was statistically significant when simple regression was performed.

According to the analysis results of the Chinese sample, CF did not significantly affect CA. Why did this result occur? In the case of Chinese consumers, there is an interest in whether companies perform social responsibility activities. However, interest in " $\mathrm{CF}$ " is relatively low as to whether an entity's social responsibility activities are appropriate for its image or characteristics.

In particular, this situation was more noticeable during the COVID-19 pandemic. For example, Wu Ling Automotive (五菱汽车) reduced its car production line and created a mask production line during the COVID-19 pandemic. Although producing mast by an automobile company is a far cry from the nature of the company, most Chinese consumers viewed the company's CA as being high.

Hypothesis 2 concerns the role of DT in the effect of CSR attributes on CA. More specifically, DT was found to provide mediating effects between CSR attributes (or CS, CF, and CI) and CA.

South Korea and China showed positive partial mediating effects between CSR attributes and CA. This means that consumers in both countries evaluate the authenticity of CSR based on whether the company's CSR activities are appropriate for the image of the company, whether the company's CSR activities are sustainable, and whether the company sufficiently addressed the social problems. In the meantime, based on empirical analyses (or mediating effects), it is suggested that the CSR attributes can affect CA more effectively through "DT".

\section{Implications and Limitations}

Overall, this study is meaningful in carrying out empirical analyses between CSR attributes and CA, and identifying the mediating effects of DT with Korean and Chinese samples. This research has the following detailed academic implications. First, this research is valuable in that it examines CSR attributes that include: (1) CF with the service or image provided, (2) CS, and (3) contribution to solving social problems (CI). Although there are some differences in factors depending on the systems and cultures in South Korea and China, the three basic attributes of CSR activities are important factors in customers' recognizing the authenticity of CSR.

Second, the role of "DT" in the era of the FIR is becoming increasingly important. However, there is little research on how DT plays a role in CSR activities and how DT is related to CSR. One example is how CA reflects the perceptions of stakeholders and customers. In fact, stakeholders and customers need to be made aware of CA. Digital en- 
vironments can validate CA claims, which can alter purchase decisions. Furthermore, this study provides empirical evidence that DT must also be considered when undertaking CSR activities.

Third, we should recognize the "differences" and "commonalities" between Korea and China. In commonalities perspective, CSR attributes and DT must be important factors in Korea and China. On the other hand, when the attributes of CSR affect the authenticity of CSR, CS in Korea and CF in China have a relatively low influence. Future research will be needed on why this phenomenon occurred. For example, is it due to cultural differences? Or are the characteristics unique to the electronics industry combined with cultural characteristics that cause this? Future research on CSR and competitiveness could provide a more meaningful approach to corporate strategy and vision.

Meanwhile, this study provides several practical implications. First, the empirical results of this research show that not only the CF but also the CS and CI among CSR activities are important factors. Therefore, if a company engages in a variety of CSR activities, it will need to consider CF, CS, and CI together.

Second, a clear mid- to long-term strategy for "CSR" and "DT" is now needed. Traditionally, CSR activities were based on donations or environmental protection. However, CSR through DT using new technologies is a future trend. It is time for a mid- to long-term plan for these goals. These efforts will eventually increase the performance of the company and lead to greater corporate competitiveness.

Finally, the logic of this study is related to the ideology of CSV (creating shared value), which seek to strengthen CSR activities and company's competitiveness simultaneously and is a desirable direction for the future [6,7].

Successful examples of CSR activities mentioned in this study include TESCO's utilization of AI analysis technology, agriculture using robots and drones, the use of drones in construction waste, and Maersk optimizing speed and route efficiency through data analysis of sensors installed on ships [61-63]. CSR and DT are now essential factors of a company's successful operations.

This study began with the question, "Does DT strengthen CSR authenticity and corporate competitiveness?" If a company's competitiveness is strengthened by DT, CSR authenticity can be performed more easily, at a lower cost, and more efficiently.

Finally, the analysis of the differences between Korea and China suggests future strategic directions for CSR activities to relevant companies and multinationals operating in these countries.

This study presented many valuable implications. Nevertheless, and it features several limitations which may help future research. First, this study was conducted mainly on consumers in the electronics industry. Therefore, it may be difficult to generalize the findings to other industries, and further analysis needs to be conducted in other industries. Second, this study can also be seen as a transdisciplinary study [66]. In our survey, questionnaire items related to DT and attributes of CSR were somewhat insufficient. Therefore, the transdisciplinary integration between the two fields needs to be somewhat supplemented. Future research will also require consideration on how to integrate the two fields effectively.

In addition to the attributes of the three CSR activities covered in this study-CS, $\mathrm{CF}$, and $\mathrm{CI}-$ future research can also consider additional attributes such as transparency and differentiation of CSR. Moreover, through continuous discussions on the criteria for judgment and evaluation by Korean and Chinese consumers and stakeholders on CSR activities, various issues should be addressed in future CSR-related research. Furthermore, while empirical research on the importance of DT is important, support such as case studies under the theme of strengthening competitiveness through CSR and DT can provide a better focus for future research. 
Author Contributions: Methodology, H.L.; Writing—review \& editing, J.-S.J. All authors have read and agreed to the published version of the manuscript.

Funding: This research received no external funding.

Conflicts of Interest: The authors declare no conflict of interest.

\author{
Abbreviations \\ FIR The Fourth Industrial Revolution \\ CF CSR Fit \\ CS CSR Sustainability \\ CI CSR Impact \\ CA CSR Authenticity \\ DT Digital Transformation
}

\title{
References
}

1. Kim, S.M.; Lee, H.J. The effect of CSR fit and CSR authenticity on the brand attitude. Sustainability 2020, 12, 275. [CrossRef]

2. Du, S.; Bhattacharya, C.B.; Sen, S. Corporate social responsibility, multi-faceted job-products, and employee outcomes. J. Bus. Eth. 2015, 131, 319-335. [CrossRef]

3. Luo, X.; Bhattacharya, C.B. Corporate social responsibility, customer satisfaction, and market value. J. Mark. 2006, 70, 1-18. [CrossRef]

4. Luo, X.; Bhattacharya, C.B. The debate over doing good: Corporate social performance, strategic marketing levers, and firmidiosyncratic risk. J. Mark. 2009, 73, 198-213. [CrossRef]

5. Choi, D.C.; Chung, C.Y.; Young, J.S. An economic analysis of corporate social responsibility in Korea. Sustainability 2019, 11, 2676. [CrossRef]

6. Porter, M.E.; Kramer, M.R. Strategy and society: The link between competitive advantage and corporate social responsibility. Harv. Bus. Rev. 2006, 84, 78-92.

7. Porter, M.E.; Kramer, M.R. Creating shared value: How to reinvent capitalism-And unleash a wave of innovation and growth Harv. Bus. Rev. 2011, 1, 62-77.

8. Vilanova, M.; Lozano, J.M.; Arenas, D. Exploring the nature of the relationship between CSR and competitiveness. J. Bus. Eth. 2009, 87, 57-69. [CrossRef]

9. Yoo, D.H.; Lee, J. The effects of corporate social responsibility (CSR) fit and CSR consistency on company evaluation: The role of CSR support. Sustainability 2018, 10, 2956. [CrossRef]

10. Park, J.; Lee, H.; Kim, C. Corporate social responsibilities, consumer trust and corporate reputation: South Korean consumers' perspectives. J. Bus. Res. 2014, 67, 295-302. [CrossRef]

11. Menon, S.; Kahn, B.E. Corporate sponsorships of philanthropic activities: When do they impact perception of sponsor brand? J. Consum. Psychol. 2003, 13, 316-327. [CrossRef]

12. Foreh, M.R.; Grier, S. When is honesty the best policy? The effect of stated company intent on consumer skepticism. J. Consum. Psychol. 2003, 13, 349-356. [CrossRef]

13. Sen, S.; Bhattacharya, C.B. Does doing good always lead to doing better? Consumer reactions to corporate social responsibility. J. Mark. Res. 2001, 38, 225-243. [CrossRef]

14. Beckman, T.; Colwell, A.; Cunningham, P.H. The emergency of corporate social responsibility in chile: The importance of authenticity and social networks. J. Bus. Eth. 2009, 86, 191-206. [CrossRef]

15. Beverland, M. The'real thing': Branding authenticity in the luxury wine trade. J. Bus. Res. 2006, 59, 251-258. [CrossRef]

16. O'Connor, A.; Shumate, M.; Meister, M. Walk the line: Active moms define corporate social responsibility. Pub. Relat. Rev. 2008, 34, 343-350. [CrossRef]

17. Carroll, A.B. A three-dimensional conceptual model of corporate social performance. Acad. Manag. Rev. 1979, 4, 497-505. [CrossRef]

18. Orbik, Z.; Zozulakova, V. Corporate social and digital responsibility. Manag. Syst. Prod. Eng. 2019, 27, 79-83. [CrossRef]

19. Vey, K.; Fandel-Meyer, T.; Zipp, J.S.; Schneider, C. Learning \& Development in times of digital transformation: Facilitating a culture of change and innovation. Int. J. Adv. Corp. Learn. 2017, 10, 22-32.

20. Park, K.S.; Ko, J.S. The problems and improvement measures of the export support system of korean SME. Int. Comm. Law Rev. 2018, 79, 209-228. [CrossRef]

21. Chandola, V. Digital transformation and sustainability. Master's thesis, Harvard University, Cambridge, MA, USA, 2015.

22. Lee, J.U.; Yoo, D.H.; Jeon, Y.H. The influence of fit and consistency of CSR activities on consumers' corporate evaluation: Focusing on the role of CSR support. Korean J. Advert. 2012, 23, 319-341.

23. Lee, M.Y.; Choi, H.C. The influence about authenticity of corporate social responsibility on the corporate attitude. Korean J. Journal. Commun. Stud. 2012, 56, 58-83.

24. Hastie, R. Causes and effects of causal attribution. J. Pers. Soc. Psychol. 1984, 46, 44-56. [CrossRef]

25. An, D.C.; Seo, K.S.; Lee, J.Y. The effect of franchisers' CSR initiatives on trust and long-term orientation of franchisees: Focusing on the role of attribution of CSR authenticity. Advert. Res. 2020, 125, 90-115. [CrossRef] 
26. Cho, J.S. Effects of fit and consistency of CSR on attitude toward LCCs' CSR activities: Focused on the mediating effect of authenticity. Tour. Res. 2019, 44, 331-353.

27. Dwyer, F.R.; Schurr, P.H.; Oh, S. Developing buyer-seller relationships. J. Mark. 1987, 51, 11-27. [CrossRef]

28. Kelly, H.H. The process of casual attribution. Am. Psychol. 1973, 28, 107-128. [CrossRef]

29. Kim, J.H.; Shin, S.H.; Kim, S.J. The influence of consistency and distinction attribution of corporate's cause-related behavior on attitude toward corporate. Korean J. Cons. Advert. Psychol. 2005, 6, 27-44.

30. L'Etang, J. Public relations and corporate social responsibility: Some issues arising. J. Bus. Eth. 1994, 13, 111-123. [CrossRef]

31. Ellen, P.S.; Webb, D.J.; Mohr, L.A. Building corporate associations: Consumer attributions for corporate socially responsible programs. J. Acad. Mark. Sci. 2006, 34, 147-157. [CrossRef]

32. Becker-Olsen, K.L.; Cudmore, A.; Hill, R.P. The impact of perceived corporate social responsibility on customer behavior. J. Bus. Res. 2006, 59, 46-53. [CrossRef]

33. Pracejus, J.W.; Olsen, G.D. The role of brand/cause fit in the effectiveness of cause-related marketing campaigns. J. Bus. Res. 2004, 57, 635-640. [CrossRef]

34. Nan, X.; Heo, K. Consumer responses to corporate social responsibility (CSR) initiatives: Examining the role of brand-cause fit in cause-related marketing. J. Advert. 2007, 36, 63-74. [CrossRef]

35. Du, S.; Bhattacharya, C.B.; Sen, S. Maximizing business returns to corporate social responsibility (CSR): The role of CSR communication. Int. J. Manag. Rev. 2010, 12, 8-19. [CrossRef]

36. Alhouti, S.; Johnson, C.M.; Holloway, B.B. Corporate social responsibility authenticity: Investigating its antecedents and outcomes. J. Bus. Res. 2016, 69, 1242-1249. [CrossRef]

37. Bae, J.Y. CSR communication factors' and personal characters' impacts on CSR evaluations. Korean J. Advert. 2014, 25, 393-423. [CrossRef]

38. Sen, S.; Bhattacharya, C.B.; Korschun, D. The Role of Corporate Social Responsibility in Strengthening Multiple Stakeholder Relationships: A Field Experiment. J. Acad. Mark. Sci. 2006, 34, 158-166. [CrossRef]

39. Mulaessa, N.; Wang, H. The effect of corporate social responsibility (CSR) activities on consumers purchase intention in China: Mediating role of consumer support for responsible business. Int. J. Mark. Stud. 2017, 9, 73-81. [CrossRef]

40. Fombrum, C.J.; Van Riel, C.B. Fame and Fortune: How Successful Companies Build Winning Reputations; FT Press: Upper Saddle River, NJ, USA, 2004.

41. Maignan, I.; Ferrell, O.C. Corporate social responsibility and marketing: An integrative framework. J. Acad. Mark. Sci. 2004, 32, 3-19. [CrossRef]

42. Holbrook, M.B. Beyond attitude structure: Toward the informational determinants of attitude. J. Mark. Res. 1978, 15, 545-556. [CrossRef]

43. Williams, O.F. CSR: Will it change the world? Hope for the future: An emerging logic in business practice. J. Corp. Citiz. 2014, 53, 9-26. [CrossRef]

44. Price, L.L.; Arnould, E.J.; Tierney, P. Going to extremes: Managing service encounters and assessing provider performance. J. Mark. 1995, 59, 83-97. [CrossRef]

45. Afzali, H.; Kim, S.S. Consumers' responses to corporate social responsibility: The mediating role of CSR authenticity. Sustainability 2021, 13, 2224. [CrossRef]

46. Park, Z.X.; Hwang, J.H. The effects of cause-related marketing on a customer's perceptions of authenticity and corporate image: Beverage product types as a moderator. Int. J. Tour Sci. 2016, 40, 59-80.

47. Choi, W.J.; Shin, J.G.; Baek, K.B. What are the important leadership competencies on the 4th Korea. Korea Bus. Rev. 2018, 22, 175-195. [CrossRef]

48. Vial, G. Understanding digital transformation: A review and a research agenda. J. Strateg. Inf. Syst. 2019, 28, 118-144. [CrossRef]

49. WEF. White paper digital transformation of industries: In collaboration with accenture digital enterprise. World Econ. Forum 2016, $1,1-16$.

50. Kim, K.W.; Park, J.S.; Kim, J.Y. A study on the promotion of digital transformation for micro enterprises: Focusing on the factors influencing digital transformation. Korea Bus. Rev. 2020, 24, 131-150. [CrossRef]

51. Kim, Y.J. Changes in the era of digital transformation and corporate countermeasures. Ind. Eng. Mag. 2018, 25, $20-24$.

52. Lee, W.H. A Study on digital transformation as a business strategy: Building a total digital business strategy framework for distribution. J. Dist. Manag. Res. 2019, 22, 85-99.

53. Deloitte Insights. Correlation between digital maturity and finance connects digital transformation to sustainable high growth. Bus. Highlights 2020, 12-23. Available online: https://www2.deloitte.com/content/dam/Deloitte/kr/Documents/consumerbusiness /2020/kr_consumer_article-20200619.pdf (accessed on 10 June 2021).

54. Kane, G.C.; Palmer, D.; Phillips, A.N.; Kiron, D.; Buckley, N. Accelerating digital innovation inside and out: Agile teams, ecosystems, and ethics. MIT Sloan Management Review and Deloitte Digital. Research Report. 2019. Available online: http:/ / www.sadil.ws/handle/123456789/14 (accessed on 10 June 2021).

55. Ku, Y.H.; Shim, J.C. A study on the mediating effects of CSR authenticity: Focusing on corporate ethical reputation, CSR consistency, and CSR transparency. J. Public Relat. 2017, 21, 1-29.

56. Choi, K.S.; Hwang, S.Y.; An, D.C. A study on the effects of motivation and attributes of corporate CSR activities on CSR authenticity and corporate attitude. J. Dist. Manag. Res. 2020, 23, 97-115.

57. An, D.C.; Wang, C.; Jeon, P.H. A comparative analysis of CSR authenticity between proactive and reactive CSR under corporate crisis: Moderating roles of company-cause fit and the firm's Prior Reputation. J. Int. Trade Commun. 2018, 14, 585-602. [CrossRef] 
58. Feroz, A.K.; Zo, H.J.; Chiravuri, A. Digital transformation and environmental sustainability: A review and research agenda. Sustainability 2021, 13, 1530. [CrossRef]

59. Hoffffman, D.L.; Novak, T.P. Consumer and object experience in the internet of things: An assemblage theory approach. J. Cons. Res. 2017, 44, 1178-1204. [CrossRef]

60. Watson, E. Tesco becomes First Corporate in the World to Align Science-Based Targets with Ambitious 1.5. View in Article. 2020. Available online: http:/ / carboncredentials.com/wp-content/uploads/2017/07/Carbon-Credentials-Tesco-SBT-case-study.pdf (accessed on 10 June 2021).

61. Dillow, C. The Construction Industry is in Love with Drones. Fortune. View in Article. 2016. Available online: https: / / fortune.com/2016/09/13/commercial-drone-construction-industry/ (accessed on 10 June 2021).

62. Scolaro, C.M. This Weed-Killing AI Robot can Tell Crops Apart. CNBC, View in Article. 2018. Available online: http://www. cnbc.com/2018/06/04/weed-killing-ai-robot.html (accessed on 10 June 2021).

63. Kemp, J. Big Data Helps Shipping Lines Cut Fuel Bills and Emissions: Kemp. Reuters, View in Article. 2015. Available online: https:/ / www.reuters.com/article/us-shipping-containers-fueloil-kemp-idUSKBN0NK1TQ20150429 (accessed on 10 June 2021).

64. Kim, B.Y.; Yoo, D.K.; Song, N.E. The impact of corporate social responsibility (CSR) activities and CSR authenticity on consumer perceived quality and brand attitude. J. Prod. Res. 2018, 36, 129-137.

65. Jose, S.J.; Khare, N.; Buchanan, F.R. Customer perceptions of CSR authenticity. Int. J. Organ. Anal. 2017, 26, 614-629. [CrossRef]

66. Hirsch Hadorn, G.; Hoffmann-Riem, H.; Biber-Klemm, S.; Grossenbacher-Mansuy, W.; Joye, D.; Pohl, C.; Wiesmann, U.; Zemp, E. Handbook of Transdisiciplinary Research; Springer: Berlin/Heidelberg, Germany, 2008. 